\title{
Ikaskuntza-Zerbitzua. Hezkuntza Komunitateko eragile ezberdinen arteko harremanak eraikitzeko eta sendotzeko bidea
}

\author{
Service-Learning. The way to strengthen relations between members \\ of the educational community
}
Garazi Ormazabal Arizkorreta*, Maitane Basasoro Ziganda, Andoni Argiñano Madrazo

Hezkuntza, Filosofia eta Antropologia Fakultatea

Euskal Herriko Unibertsitatea, Donostia, Gipuzkoa

\begin{abstract}
LABURPENA: Hezkuntzak egungo herritar diren haur zein gazteak bizitzarako prestatu behar dituela adituta, ezinbestekoa izango da, horren bitartez, bizitza eta ikaskuntzaren arteko lotura bermatzea. Eginbide horretan, Ikaskuntza-Zerbitzua (I-Z), mundu errealaren eta eskolaren arteko lotura ezartzen duen metodologia eredugarri bilakatu da. Kasuan kasu, azterketa hau, Portugaleteko Santa Maria ikastetxean kokatu da. Bertan, Batxilergoan 22 urteko ibilbidea duen I-Zren baitako esperientzia bat aurkitu baita. Hortaz, hurrengoa da ikerlan honen bidez eskuratu nahi izan den helburua: I-Zren bidez Santa Maria ikastetxeko hezkuntza komunitateko eragileen artean sortzen diren harremanak aztertzea. Horretarako, azterketa honetan diseinu kualitatibo bat jarraitu da eta, honen baitan, kasu azterketaren metodoa hautatu da. Honenbestez, hurrengo azterketa, I-Zren gaian aditua den ikastetxeko kide bati egindako estandarizatu gabeko bi elkarrizketetan eta 31 dokumenturen analisian oinarritu da. Eskuratutako informazioaren kategorizazio zein kodifikazioa burutu ostean, emaitza aipagarri ugari eskuratu dira: ikasleen eta irakasle -ikasleen arteko harremanak hobetzen dituen eta eskola zein komunitatearen artean loturak bultzatzen dituen esperientzia ezagutu da.
\end{abstract}

GAKO-HITZAK: ikaskuntza-zerbitzua, batxilergoa, ikasle-ikasle harremana, irakasle-ikasle harremana, eskola-familia harremana, eskola-komunitate harremana.

ABSTRACT: Education has the duty to prepare children and young people for life as today's citizens; so it is essential to guarantee the relationship between life and learning. In this task, Service Learning (I-Z) has become an exemplary methodology that links the real world with the school. In this case, the study has been located in the school Santa Maria of Portugalete, as a 22-year S-L High School experience has been found. Thus, the aim of this study is to analyse the relationships established through $S-L$ between the different agents of the educational community in the school Santa Maria. In order to acquire as much knowledge as possible, a qualitative design has been followed, using the case study method. Therefore, the research is based on two non-standardized interviews that have been made to an expert of $S-L$ and on the analysis of 31 documents. After categorising and coding the information obtained, a number of noteworthy results were obtained: it has been known an experience that improves relations between students and teacher-students and fosters links between the school and the community.

KEYWORDS: service-learning, higher education, peer relashionship, student teacher relationship, parent school relationship, school community relationship.

* Harremanetan jartzeko/ Corresponding author: Garazi Ormazabal Arizkorreta. UPV/EHU. Didaktika eta Eskola Antolakuntza. Hezkuntza, Filosofia eta Antropologia Fakultatea. Tolosa Hiribidea 70 (20018 Donostia. Gipuzkoa). - gormazabal8@gmail. com - https://orcid.org/0000-0002-2554-9484

Nola aipatu / How to cite: Ormazabal Arizkorreta, Garazi; Basasoro Ziganda, Maitane: Argiñano Madrazo, Andoni (2021). "lkaskuntza-Zerbitzua. Hezkuntza Komunitateko eragile ezberdinen arteko harremanak eraikitzeko eta sendotzeko bidea». Tantak, 33(1), 83-105. (https://doi.org/10.1387/tantak.22119).

Jasotze-data: 2020/10/07; Onartze-data: 2020/12/18

ISSN 0214-9753 - elSSN 2444-3581 / (c) 2021 UPV/EHU

cc)(-) $\odot$ Lan hau Creative Commons Aitortu-EzKomertziala-LanEratorririkGabe 4.0 Nazioartekoa

lizentzia baten mende dago 


\section{SARRERA}

Bidegurutze sozial eta hezitzaile batean gaude. Gure kulturak indibidualismo arriskutsu baterantz eboluzionatu du. Norbanakoaren askatasun eta eskubideen defentsan oinarritzen da, azken auzitegi gisa duen kontzientziaren apelazioan, garapen pertsonalarekiko kezkan. Hori guztia lorpen sozial handia den arren, gizartean bizi garen kontzientzia argia berreskuratzen ez badugu, eta norbanakoak bere proiektu pertsonala garatu ahal izateko lotura sozialak ezinbestekoak direla ulertzen ez badugu, aipatutako oro alferrikakoa izango da. (Batlle, 2013, 6 or.)

Esanak esan, gaur egungo hezkuntzaren xedea zein den galdetzea beharrezkoa ikusten da; hezkuntza, banakoaren konpetentzia zein curriculumaren garapena bermatzeaz harago doala ondorioztatuz. Are gehiago, hezkuntzak egungo herritar diren haur eta gazteak bizitzarako prestatzeko ardura duela ulertzen badugu, aipatutako konpetentzia horiek garatzea ez da nahikoa izango. Izan ere, garen izaki sozialak izanda, herritartasunerako heziketa jasotzea ere beharrezko bihurtzen da. Horren bitartez, gizarteko kide ezberdinen arteko kohesioa bermatzen dela ikusi baita (Batlle, 2013). Ondorioz, komunitateak pertsona ororen hezkuntza zein hazkuntza prozesuan duen garrantzia nabaria izanik, eskolak duen formatzaile paper hori birplanteatzea nahitaezkoa da, haur baten heziketan garrantzitsuak diren agenteei beharrezko espazioa eskainiz (Bolívar, 2006). Ikaskuntza-Zerbitzua (hemendik aurrera I-Z), besteak beste, lotura horiek ezartzen dituen metodologia eredugarri bihurtu da.

Hainbat dira I-Zren baitan aurkitu daitezkeen definizioak; izan ere, batzuek ikaskuntza esperientzialarekin lotzen duten arren, beste batzuek, metodologia pedagogiko gisa ulertzen dute (Furco, 1996). Halaber, jarraian garatuko den lan hau Tapia-k (2000), Puig et al.-ek (2007) eta Mendia-k (2000) adierazitako ideietan oinarritu da, I-Z segidan azalduko den moduan ulertuz.

I-Z hezkuntza zein komunitate zerbitzua proiektu batean batzen dituen hezkuntza metodologia da. Bertan, ikasleek beren inguruan dauden beharrak identifikatu eta behar horiek asetzeko erantzunak ematen dituzte. Ondorioz, prozesu horretan eskuratzen dute ikaskuntza (Puig et al., 2007). Zehatzago esanda, ikasleek proiektu hauetan ezagutzak zein konpetentziak garatzen dituzte: alde batetik, eskolako edukiak hobeto eskuratu eta, bestetik, eskola eta komunitatearen arteko elkarlanaz ardura handiko eginkizunak burutzen baitituzte (Tapia, 2000). Horrez gain, Puig et al.-ek (2007) emandako azken definizio horretan oinarrituz, Mendia-k (2012, 73. or.) I-Zren inguruan adierazitakoa azpimarratu nahi da: «Azken finean, ikaskuntzari bizia ematea da; ikaskuntza bizitzara edo bizitza ikaskuntzara hurbiltzea, hau da, desira ereitea, aurkikuntzaren alaitasuna 
gozatzea eta interesaren, hausnarketaren zein analisiaren erresistentziak eraldatzea».

Bizitza ikaskuntzara hurbiltzeak ikaslearen baliabide pertsonalak hobetzea esan nahi du; honela, bizitzan zehar agertuko zaizkion erronkei aurre egiteko gai izan dadin. Horrez gain, ikasleak beren garapenaren protagonista gisa kokatzea, eta haur zein gazteei beren hazkunde pertsonalean eta gizarte-erantzukizunetan lagunduko dien hezkuntza-komunitatea eraikitzea ahalbidetzen du I-Zk.

Horrenbestez, esan daiteke I-Zren bidez ikaslea bere ikaskuntza prozesuko protagonista nagusi bihurtzen dela. Areago, bere garapen pertsonaleko ibilbide horretan, herritar bezala dituen ardurez ere jabetzen da (Mendia, 2012).

\section{IKASKUNTZA-ZERBITZUA ETA ESKOLA-KOMUNITATE HARREMANAK}

Justiziaren etika zorrotzak ez garamatza zuzenean Ikaskuntza-Zerbitzuaren ontasuna bermatzera. I-Z zaintzaren etikan kokatzen da. Mundua erantzukizunezko harreman-saretzat hartzen baitu, pertsonen arteko topaketatzat, non denok saiatu behar garen guztiontzako ongirik handiena lortzen. Horretarako, desberdintasunei erreparatu behar zaie: agian batzuentzat bidezkoa dena besteentzat ez baita horrela izango. Zaintzaren etikan ezer ez zaigu arrotza, ezerk ez gaitu axolagabe uzten; edozein bidegabekeria- edo desberdintasun-egoerak, zuzenean eragiten ez badigu ere, hura konpontzeko ekintza bat merezi du. (Batlle, 2020 , 19. or.)

Zaintzaren etikan oinarrituz, hortaz, Ikaskuntza-Zerbitzuaren bitartez, komunitate zein eskolaren arteko loturak sortzen direla ikusi da. Proiektu komunak partekatuz, batera lan egin, iritziak elkar banatu eta hobekuntzarako ekintza planak denen artean eraikitzen baitira (Puig et al., 2007).

Topaketa horietan loratzen diren harremanei arreta jarriz gero, Ikaskuntza-Zerbitzuaren bitartez, eskola eremuko harremanak indartzen direla frogatu da, metodologia horren bidez, eskola kohesioa eskuratzen baita. Hau da, ikasleen arteko zein irakasle-ikasle arteko harreman positiboak eraikitzen dira (Billing, 2000). Izan ere, I-Zko proiektuetan ikasleek duten parte hartze motaren ondorioz, eskola komunitateko kide ezberdinen rolen inguruko hausnarketa bultzatzen da (Serrano eta Ochoa, 2019). Hots, «I-Zko proiektu on batek irakaslearen lidergo-mota zehatz bat eskatzen du, hau da, sarritan, irakasleek eta ikasleek (...) elkarrekin ikasi beharko dute, eta irtenbide berritzaileak elkarrekin sortu» (Tapia, 2006, 3. or.). Ondorioz, irakasle eta ikasleen arteko harreman horizontalak sortzen dira (Serrano 
eta Ochoa, 2019) eta ikasleak irakaslea beste testuinguru batean ezagutzera iristen dira (Tapia, 2006).

Aitzitik, irakasle zein administrazioko kide batzuk metodologia horren aurka azaltzen direla ere frogatu da; hori aurrera eramateko denbora gehiago behar dutela esateaz gain, praktika horiek ikaskuntza tradizionalari indarra kentzen diotela adierazten baitute. Halaber, ezin dira ukatu ikasleek horrelako metodologietan lan egitearekin eskuratzen dituzten onurak (Scott eta Graham, 2015).

Bestetik, I-Z proiektuetan ikasleek lortzen duten arrakastaren bitartez, ikaslearen motibazioa areagotzeaz gain, haren autoestimua garatzen dela ere egiaztatu da. Batez ere, gainontzekoekin alderatuta zailtasun gehiago izan ditzaketen ikasleen kasuan. Areago, ikaslearengan ematen den indartze pauso horrekin batera, ikasgelako klima ere hobetzen da (Batlle, 2013; Tapia, 2006). Ikasgelako klimak, Herrera-ren eta Rico-ren hitzetan (2014, 9. or.), ikastetxean ematen diren elkarrekintza ereduei egiten die erreferentzia, zehatzago esanda, «une zein testuinguru zehatzetan, eskolako partaide ezberdinen artean sortzen diren interakzioen prozesua da. Elkarrekintza horretan, estimulu, erantzun eta iritzi ezberdinak partekatzen dira. Bertan biltzen diren maila sozial eta egoera psikologiko oro onartzen dira». Ildo beretik jarraituz, Puig et al.-ek (2007) ere, metodologia honek eskolako kliman duen eraginaz hitz egiten dute. I-Zko proiektuetan parte hartzen duten ikasle zein irakasleen motibazioa, umorea eta lan egiteko dohaina areagotu egiten dela azpimarratuz. Are gehiago, sor daitezkeen kritikei aurre eginez berrikuntzarako gogoa ere pizten zaiela adierazten dute.

Eskola eremutik aldenduz, Ikaskuntza-Zerbitzua ikasleak eta komunitateko kideak aberasten dituen prozesu gisa aditu liteke (Yamauchi et al., 2006). Izan ere, I-Zren metodologian, burutzen diren proiektuen bitartez lortzen da komunitatearekin harremanak eraikitzea. Hots, lotura horretan oinarritzen da I-Zren aberastasuna. Bestetik, Batlle-k (2013) adierazi bezala, komunitateari zerbitzu bat eskaintzearen ondorioz ikasten da I-Zn. Autore horren arabera, herritartasuneko hezkuntza komunitatean burutzen diren praktiken bitartez soilik eskuratu ahal baitaiteke. Hortaz, I-Z hezkuntza zein gizarteko proiektu bezala aditu behar da (Batlle, 2013).

Ildo beretik, hezkuntza-formakuntza bermatu ez ezik, gizarteko kideen arteko kohesioa ere ziurtatzen da Ikaskuntza-Zerbitzuan (Batlle, 2013). Izan ere, ikasleek I-Zko proiektuetan parte hartzean, taldean lan egiteko trebetasunak eskuratzeaz gain, belaunaldi ezberdinetako jendearekin harremanak izaten zein aktiboki esku hartzen ikasten dute (Martínez-Odría, 2007). Bestetik, I-Z hiriko adin ezberdinetako kideen arteko komunikazioa hobetzen duen metodologia dela esan daiteke (Batlle, 2011). Ondorioz, metodologia horren bidez ikasleen gaitasun komunikatiboa hobetzen da (Billing, 2002).

Horrenbestez, praktika horiek burutzean, haur, gazte, heldu zein adinekoen artean egon litezkeen topikoak gainditu eta harreman sendoagoak lo- 
ratzen direla ikusi da (Batlle, 2011). Hau da, esan daiteke Ikaskuntza-Zerbitzuak herritarren arteko kohesio hori indartu eta inguruarekiko jarrera zein sentimendu positiboak garatzea ahalbidetzen duela (Puig et al., 2011), arestian aipatutako zaintzaren etika hori eskuratuz (Batlle, 2020). Azken finean, egitasmo horien bidez, gazte zein haurrek beren inguruko errealitatea hobetzeko ekarpenak burutzeko aukera baitute (Martínez-Odría, 2007).

I-Zko proiektuetan esku hartzen duten familiei dagokienez, sarritan lan egiteko modu horren inguruko kezka adierazi izan ohi dute. Metodologia horren inguruan zenbait aurreiritzi izan baititzakete. Hortaz, beldur horiei aurre egiteko modua komunitatea eta eskolaren arteko loturaren garrantzia zein den erakustea izango litzateke. Egiteko horretan, irakasleek ardura garrantzitsua dute. Bestetik, komunitateko kide orok proiektuaren nondik-norakoak ezagutzea ezinbestekoa izango da. Horrela, proiektuko protagonistenen rola hartu ahal izateaz gain, «hezkuntza-espazioaren» lekua beren gain hartu ahal dezaten (Montes et al., 2011).

Prozesu horietan gertatzen diren elkarreraginekin jarraikiz, eskolak auzoarekiko ateak zabaltzen dituenez, zenbait elkarterekin harreman estuagoak sortzen dira. Horrela, eskolaren inguruan dauden elkarteak ezagutzeko aukera bermatu ez ezik, herritarrek gazte edota haurrekiko dituzten aurreiritziak apurtzen dituzte (Batlle, 2013). Ondorioz, eskolak herrian aitorpen bat lortzen duela esan daiteke (Puig et al., 2007). Hots, I-Zren bitartez eskolarekin harremana duten elkarteei dagokienez, herritarrak sentsibilizatzeko zein horien eskutik laguntza gehiago jasotzeko aukera areagotzen dela ikusi da. Izan ere, ikusgarritasun gehiago lortzeaz gain, burutzen duten lanaren inguruko kontzientzia zabaltzea lortzen dute (Puig et al., 2007).

Hortaz, metodologia honetan, Bolívar-en (2006) hezkuntzaren inguruko ideiak betetzen direla esan daiteke. Izan ere, hezkuntzak ez du eskola barneko jendartekoari zuzenduriko hezkuntza soilik biltzen. Aitzitik, eskolaz kanpoko pertsonak ere biltzen ditu; eskolatik at daudenak ere baliabide hezitzaile gisa balioztatzen dira. Horrenbestez, komunitateak pertsona ororen hezkuntza zein hazkuntza prozesuan duen garrantzia nabaria izanik, eskolak duen formatzaile paper hori zalantzan jartzen da, bide batez haur baten heziketan garrantzitsuak diren agenteei ere beharrezko espazioa eskainiz (Bolívar, 2006).

Adierazitako oro aintzat hartuta, eskuarteko azterketa honen testuinguruan kokatzearren, azterketaren alderdi nagusia izan den Portugaleteko Santa Maria ikastetxearen kasua aztertzea interesgarria gertatu da. Bertan, Batxilergoko ikasleen etorkizuneko ikasketak burutzeko baliagarriak izango diren konpetentziez harago joan nahi izatearen ondorioz, Batxilergoko etapan I-Zren metodologia biltzen duen ikasgai bat ezarri da. Hori ikastetxearen nortasun zeinu bilakatu delarik. Izan ere, metodologia horren bitartez ikaskuntza bizitzara eta bizitza ikaskuntzara hurbildu ez ezik, ikasleek bizitzan zehar topa ditzaketen erronkei aurre egiteko baliabide pertsonalak ere eskuratzen dituztela ikusi da (Mendia, 2012). 


\section{HELBURUAK}

Orain artekoa aintzat hartuz, azterketa honen bidez hurrengo helburu nagusia eskuratu nahi izan da. Horretarako beraz, helburu zehatz batzuk ere definitu dira:

I-Zren bidez Santa Maria ikastetxeko hezkuntza komunitateko eragileen artean sortzen diren harremanak aztertzea:

- Ikasle-irakasleen arteko harremanak aztertzea.

- Ikasleen arteko harremanak aztertzea.

- Eskola-familia arteko harremanak aztertzea.

- Ikasle-komunitate arteko harremanak aztertzea eta haien onura zein mugak identifikatzea.

\section{METODOA}

Ikerlan hau paradigma interpretatiboan kokatzen da; hori «hezkuntza errealitatearen ikerketa, interpretazio subjektiboen eta errealitate zehatz batzuen protagonista diren pertsonen esanahien ondorioz sortzen den eraikuntza sozial gisa ulertu baita» (Bisquerra, 2004, 74 or.). Horrenbestez, autore berarekin jarraikiz, paradigma honetan, ikerketaren parte-hartzaileen iritziek garrantzi handia hartzen dute. Zehatzago esanda, bertan, pertsonen esanahi, pertzepzio zein interesak aintzat hartzen dira.

Ondorioz, aztertu nahi izan den kasua errotik ulertzeko, ikerketa prozesu guztian diseinu kualitatibo bat jarraitzea beharrezkotzat ikusi da (Bisquerra, 2004). Diseinu kualitatiboak pertsonen errealitatea era arrazional zein kuantifikatuan aztertzea alde batera utzi eta pertsonen hitzak zein jokabideak biltzen ditu (Mesias, 2010). Horiek guztiak modu deskribatzailean adierazteko parada ere eskaintzen duelarik (Quecedo eta Castaño, 2003). Bestetik, ikerketa kualitatibo honek jarraituko duen metodoari dagokionez, lan honetan, ezagutza zein ulermen sakona bilatu nahi izan denez, kasu azterketaren metodoa jarraitzea erabaki da. Izan ere, azterketa hau denbora labur batean (zein luzean) errealitate zehatz bat sakonki ezagutzea ahalbidetzen duen ikerketa mota gisa identifikatzen da (Karrera, 2008).

\section{TESTUINGURUA ETA PARTE HARTZAILEAK}

Burutu den azterketa hau Portugaleteko Santa Maria ikastetxean kokatzen da. Santa Maria Haur Hezkuntzatik (HH) hasi eta Batxilergora arte, biak barne, dauden hezkuntza etapak biltzen dituen ikastetxe kristau zein menesiarra da (Santa Maria Ikastetxea, 2020). Ikastetxe hori erakunde garrantzitsua izan da Portugaleteko azken mendeko bizitzan; bertako ikasle gazteak hezteko moduagatik gizarte-aldaketaren erreferente bilakatu baita 
(Santa Maria Ikastetxea, 2016). Aipatutako alderdi horrek, ikerketa honen funtsarekin lotura garbia du. Izan ere, ikastetxe horren bereizgarria da I-Z.

Santa Marian 1997. urtean ezarri zen lehen aldiz I-Z, Menesiarren kongregazioak egin nahi zuen berrikuntza pedagogiko baten ondorioz. Lehen urte horietan, ikastetxeko zuzendaritzak Ikaskuntza-Zerbitzua Batxilergoko lehen mailako curriculumaren barnean sartzeko proposamena egin zuen arren, erlijioko ikasgaiaren barnean kokatu zen hori. Egungo egoera aztertuz gero, I-Z Batxilergoko ikasgai baten barnean kokatzea lortu da. Zehaztearren, Proyecto de Educación Social (hemendik aurrera PES) proiektuaren bidez burutzen da. Aipatutako egitasmo horretan, ikasturte osoko aste guztietan, Batxilergoko ikasleak Portugaleteko elkarte zehatz batera joaten dira. Hori horrela, astero burutzen da, hasiera batean bezala, bi alderditan banatuta: batetik, ikastetxean burutzen den saio teorikoa; eta, bestetik, elkarteetan burutzen den atal praktikoa. Horrez gain, I-Zk eskaintzen dituen aukera anitzei jarraikiz, familia, ikasle-ohi zein irakasleak ere esperientzia horien parte direla ikusi da, laguntzaile gisa ikasleekin batera saio praktiko hori burutzeko aukera baitute. Bestetik, proiektu horien ebaluazioan ere, hainbat dira aintzat hartzen diren ikuspuntuak, hala nola ikasle, laguntzaile, elkartetako kide zein ikasgaiko irakaslearena, hain zuzen.

Hortaz, ikasgai horretan Batxilergoko ikasleek elkartasunezko praktikak egiten dituzte, ondorengo helburuak eskuratzeko asmoz: beren ingurunean dauden errealitate sozialak ezagutzea, beren inguruan sentsibilizatzea eta haiekiko konpromisoa hartzea, hain zuzen (Santa Maria Ikastetxea, 2020).

Ildo beretik, lan hau kokatu den hezkuntza etapari erreparatuz, honakoa bi modalitatetan banatzen da: teknologia eta zientzia Batxilergoa, eta gizarte eta humanitateko Batxilergoa. Bi ikasbide horietako ikasle orok hurrengo ikasgaiak derrigorrez burutu behar dituzte. Ikaskuntza-Zerbitzura itzuliz, ondorengo taulan adierazi bezala, PES proiektua biltzen duen ikasgaia Batxilergoko lehen urtean derrigorrez egin behar den arren, bigarrenean hautazko bihurtzen da (ikusi 1. taula):

\section{1. taula}

Santa Maria ikastetxeko Batxilergoko bi kurtsoetako ikasgai orokorrak. Geuk sortua, Santa Maria Ikastetxean (2020) oinarrituta

\begin{tabular}{l|l}
\hline \multicolumn{1}{c|}{ 1. Batxilergoko ikasgai orokorrak } & \multicolumn{1}{|c}{ 2. Batxilergoko ikasgai orokorrak } \\
\hline Gorputz hezkuntza & Historia \\
Filosofia eta herritartasuna & Matematika \\
Euskara eta literatura & Euskara eta literatura \\
Gaztelania eta literatura & Gaztelania eta literatura \\
Atzerriko hizkuntza & Atzerriko hizkuntza \\
PES, erlijioa eta tutoretza & Tutoretza eta erlijioa \\
\hline
\end{tabular}


Ikerlan honen protagonista nagusia da Santa Maria ikastetxeko pastoralaren ardura duen Derrigorrezko Bigarren Hezkuntzako (DBH) laugarren mailako talde baten tutorea. Formazioz, gizarte hezitzailea zein Bigarren Hezkuntzako irakaslea da eta 23 urte darama ikastetxean lanean. Bestetik, I-Zren inguruan hainbat formakuntza jaso eta eskaintzeaz gain, emakume horrek ikastetxeko hainbat profesionalekin batera Innova taldean zenbait ardura ditu. Talde horretan, Ikaskuntza-Zerbitzuko proiektuak koordinatzen zein gidatzen aritzen dira.

\section{INFORMAZIOA JASOTZEKO TEKNIKAK}

Izaera kualitatiboa duen ikerlana dela adierazi ondoren, aurrera eramateko hautatu diren prozesuek ere izaera kualitatibo horri jarraitu diotela nabaria da. Izan ere, lan hau, batetik, estandarizatu gabeko elkarrizketa batean eta, bestetik, ikastetxetik eskuratu diren 31 dokumenturen analisian oinarritu da, hala nola Batxilergoko 2019-2020 ikasturteko programazioak, PES proiektuaren inguruko txostenak zein errubrikak, eta ikasturte hasierako hezkuntza etapa bakoitzeko argibide orokorren azalpen orriak. Halaber, aipatutako tresnen bitartez, eskuratutako informazioaren analisiaren ostean, beste elkarrizketa bat egitea beharrezko ikusi da. Horrela, geratu diren hutsune edota zalantza horiek osatzeko aukera bermatu da. Ikerlana, hortaz, ordu eta erdiko estandarizatu gabeko bi elkarrizketatan eta dokumentuen analisian oinarritu da. Lehenengo elkarrizketa azterketaren helburuak betetzeko 4 galdera irekiz osatu da. Hots, horien bidez, ikasleen, irakasle-ikasleen, eskola-komunitate zein familia-eskolaren artean sortzen diren harremanen inguruan galdetu da. Dokumentuen bitartez, berriz, metodologia horrek ikastetxeko curriculumean duen lekua ez ezik, Batxilergoko etapan aurrera eramaten den esperientziaren inguruan ere sakondu da. Bigarren elkarrizketari dagokionez, aurreko tresnen bitartez eskuratutako informazioa osatu zein biribiltzeko erabili da.

Ikerlan honetan estandarizatu gabeko elkarrizketa zein dokumentuen analisia burutzearen aldeko apustua egin da. Izan ere, elkarrizketa, bi pertsonen artean oinarri zientifiko zein prozedura metodologiko zehatz batzuk bilduz ematen den komunikazioa dela ulertuta, horren bidez, fidagarritasun zein balioa duen informazioa eskuratu da (Karrera, 2008). Are gehiago, elkarrizketatzailea elkarrizketatuaren ezaugarrietara egokitzea lortu da, eta informazio subjektibo zein biografikoa eskuratzeko aukera ere areagotu egin da (Del Rincón et al., 1995). Horrez gain, kasu honetan burutu diren elkarrizketak elkarrizketa sakonak izan dira. Horiek elkarrizketatuaren zein elkarrizketatzailearen bizitza, esperientziak, zein egoera zehatzak partekatu zein ulertzea ahalbidetu duten topaketak izan baitira; berdinen arteko elkarrizketak izango balira bezala (Taylor eta Bogdan, 1984). 
Atal honekin amaitzeko, datu eskuraketa hau aberastu duen dokumentuen analisiaren teknikari dagokionez, berriz, Woods-ek (1989) adierazi bezala, dokumentuak informazioa eskuratzeko iturri garrantzitsuak izanda, haien bitartez, une zehatz batean modu pertsonalean eskuratu ezin izan diren datuak eskuratzeko aukera izan da. Hortaz, aipatutako azken teknika hori azterketaren helburuak betetzeko ezinbestekoa izan da. Ikerlan honetan erabili diren dokumentuei dagokienez, ondoren azalduko den analisia burutzeko aintzat hartu dira, batetik, elkarrizketatuak Santa Maria ikastetxeko Batxilergoko I-Z esperientziaren inguruan helarazitako dokumentuak eta, bestetik, eskuratu ahal izan diren ikastetxeko dokumentuak zein ikasturteko programazioak.

\section{INFORMAZIOAREN ANALISIAREN PROZEDURA}

Eskuratutako informazio oro aztertzeko datuen analisiari ekin zaio. Analisiaren bitartez, besteak beste, ahozko komunikazioan eskuratzen den informazioa aztertzen da (Travers, 1971; Karrera, 2008). Hori dela eta, horren bitartez, Echeverría-k (2005) adierazitakoari jarraikiz, azterketaren parte diren subjektuen testu zein ahozko adierazpenen baitan dagoen esanahia ezagutu ahal izan da; horretarako, bestearen ikuspegian kokatzea ezinbestekoa izan da. Hortaz, eskuratutako datuak lantzeko era induktibo batean jardun da.

Oro har, hiru dira emaitzen analisian igaro beharreko faseak (Karrera, 2008); azterketa honetan ere, horiek hartu dira aintzat. Lehenengo fasean, analisiaren bitartez zer aztertu nahi den, eta analisi hori zein ideiaren gainean burutu den zehaztu da. Hots, bi elkarrizketa zein dokumentuetatik eskuratutako informazio oro deskonposatu, eta aztertu nahi denaren hautaketa egin da. Pauso horren ostean, berriz, analisiaren arrakasta baldintzatzen duen pausoa burutu da: kategorizazioa, hain zuzen (Karrera, 2008). Kategorizazioa Bardin-en (1996, 90 or.) hitzei jarraikiz, azterketako informazioa antolatzeko burutzen den prozesua da. Zehatzago esanda, «bereizketa baten bitartez elementuak multzokatu zein sailkatzeko burutzen den eragiketa da. Aurrez definitutako irizpideetan oinarrituz, analogia bidezko klasifikazioa burutzen duena». Definizio horri jarraituz hortaz, ikerlan honetako kategoriak ere, zehaztasunez eraikitzea beharrezkoa izan da.

Horrenbestez, kasu honetan, hasiera batean, ikerketaren abiapuntu eta oinarri izan diren helburu eta literatura kontuan izanik kategoria batzuk definitu ziren arren (Abela, 2002), sistema kategoriala osatzeko, bi elkarrizketen transkribapenean zein dokumentuen analisian eskuratutako informazioan oinarritzea erabaki da. Ondorioz, analisi horretan agertu diren kategoria berriak aintzat hartuz, azkenik, sistema kategorial induktiboa osatu da. Esanak esan, ondorengoak dira azterketa honetan hautatu diren kategoriak eta bakoitzak biltzen duten esanahiak (ikusi 2. taula): 
2. taula

Emaitzen analisiko kategoriak eta haien azalpena. Geuk sortua

\begin{tabular}{c|l}
\hline Kategoriaren izena & \multicolumn{1}{c}{ Kategoriaren azalpena } \\
\hline PES proiektua & $\begin{array}{l}\text { PES proiektuaren osaera: edukiak, parte-hartzaileak, par- } \\
\text { taide bakoitzaren egitekoa, ebaluazioa, etab. }\end{array}$ \\
\hline $\begin{array}{c}\text { Irakasle-ikasleen } \\
\text { harremanetan onurak }\end{array}$ & $\begin{array}{l}\text { I-Z proiektuak burutzean irakasle eta ikasleen arteko ha- } \\
\text { rremanetan agertzen diren onurak. }\end{array}$ \\
\hline $\begin{array}{c}\text { Ikasleen } \\
\text { harremanetan onurak }\end{array}$ & $\begin{array}{l}\text { I-Z proiektuak burutzean ikasleen arteko harremanetan } \\
\text { agertzen diren onurak. }\end{array}$ \\
\hline $\begin{array}{c}\text { Familien eta } \\
\text { eskolaren } \\
\text { harremanetan onurak }\end{array}$ & $\begin{array}{l}\text { I-Z proiektuak burutzean familien eta eskolaren arteko ha- } \\
\text { rremanetan agertzen diren onurak. }\end{array}$ \\
\hline $\begin{array}{c}\text { Ikasleen eta } \\
\text { komunitatearen } \\
\text { harremanetan onurak }\end{array}$ & $\begin{array}{l}\text { I-Z proiektuak burutzean ikasleen eta komunitateko ki- } \\
\text { deen arteko harremanetan agertzen diren onurak. }\end{array}$ \\
\hline $\begin{array}{c}\text { Eskolaren eta } \\
\text { komunitatearen } \\
\text { harremanetan onurak }\end{array}$ & $\begin{array}{l}\text { I-Z proiektuak burutzean eskolaren eta komunitateko ki- } \\
\text { deen arteko harremanetan agertzen diren onurak. }\end{array}$ \\
\hline $\begin{array}{c}\text { Eskola eta } \\
\text { komunitatearen } \\
\text { harremanetan mugak }\end{array}$ & $\begin{array}{l}\text { I-Z proiektuak burutzean komunitatea eta eskolaren harre- } \\
\text { manetan agertzen diren zailtasunak. }\end{array}$ \\
\hline
\end{tabular}

Kategorizazioa burutu ostean, kodifikazioa osatu da. Pauso horretan, eskuratutako datu edota informazio oro kategoria zehatz batzuetan taldekatu da, eta, horretarako, operazio anitzak erabili dira. Hots, kode bakoitza dagokion kategorian txertatu da; horrela, lortutako informazioa antzekotasunen arabera antolatu da. Prozesu hau eskuz burutu dela aipatu beharra dago. Azkenik, Karrerak (2008) adierazitako analisiaren faseekin jarraituz, bigarren fasean, informazioaren aurkezpena burutu ostean, hirugarren fasean, informazioaren analisia zein interpretazioari ekin zaio.

Halaber, Karrerak (2008) dioen modura, analisi esanguratsu bat burutzeko aipatutako prozeduraz harago joan beharra dago. Horretarako, kasuikerlan honetan ere, datuen triangulazioa beharrezkoa izan da; horren bitartez, eskuratutako emaitzen egiatasuna ziurtatu ahal izan dela frogatu da (Karrera, 2008). Kasu honetan, burutu diren bi elkarrizketetan zein eskuratutako dokumentuetatik lortutako datuak konparatu dira. 


\section{EMAITZAK}

\subsection{PES proiektua}

Azterketa honetan aztergai den Batxilergoari dagokionez, PES proiektua da, Santa Maria ikastetxean, Ikaskuntza-Zerbitzuaren metodologia bidez burutzen proiekturik azpimarragarriena. Proiektu hori, erlijioko irakasleen proposamenen ondorioz, duela lau urtetik, erlijioko irakasgaiaren barnean sartzen da, hau da, PES Batxilergoko programazioaren parte da: «Zer egin genuen? Irakasleen artean komentatu genuen (...) gure kasuan Apezpikutzak normalean markatzen duen curriculumaren zati bat mantenduz, (...) Zergatik ez? Erlijio-kulturaren zatia jasotzeaz gain, oso esperientzia esanguratsuak bilduko dituen irakasgai bat egitea edo aurkeztea pentsatu genuen: bata, PES, inguruarekiko ekintza solidarioa biltzen duena, eta bestea, (...) Barnekotasunerako Hezkuntzari buruzkoa, Batxilergoko ikasleak Haur Hezkuntzako 4 urteko ikasleekin lotzen dituena» (E2/IZ. $\left.1 \_8\right)^{1}$.

Proposamen hori onartu egin zela dio elkarrizketatuak. Duela lau urte ikasgai hori hiru zutabetan banatzen da: «Ikasgaiaren barruan (...) hiru hanka daude: bata, erlijio-kultura; bestea, Solidaritaterako Hezkuntza; eta, bestea, Barnekotasunerako Hezkuntza. Solidaritaterako eta Barnekotasunerako Hezkuntzak irakasgaiaren pisuaren \% 40 dute. Bien artean, $\%$ 80. Eta gainerako \% 20 erlijio-kultura da «(E2/IZ. 2_1) ${ }^{2}$. Ondorioz, I-Zra itzuliz, ikasgaiaren \% 80 betetzen du metodologia honek. Izan ere, I-Z proiektuak eskolaz kanpo edo barnean izan dezaketela gogoan izanik, Barnekotasunerako Hezkuntzaren arloaren bitartez, I-Z eskola eremura mugatzen den bitartean; PES proiektuaren bitartez, oro har, eskola eta inguruaren arteko harremana bermatzen da, eta eskolako ateak hirira zabaltzen dira.

PES proiektuan murgilduz, ondorengoa da horren bitartez eskuratu nahi den helburua: «Ikasleek bizi diren ingurunean dauden errealitate sozialekiko duten ezagutza, sentsibilizazioa eta konpromisoa eskuratzea,

\footnotetext{
1 «Qué hicimos?, Comentamos entre los profes, (...) manteniendo parte del currículum que normalmente en nuestro caso lo marca el Obispado. (...) Dijimos ¿Por qué no hacerlo? Hacer o sea presentar una asignatura que recoja la parte de cultura religiosa, pero que recoja experiencias muy potentes: una, la del PES, que es la acción solidaria con el entorno, y otra (...) de Educación para la Interioridad, que lo que hace es vincular alumnado de bachillerato con alumnado de 4 años del cole» (E2/IZ.1_8).

2 «Dentro de la asignatura (...) hay tres patas una que es cultura-religiosa; otra que es Educación para la Solidaridad, y otra que es Educación para la Interioridad. (...) Cada una de ellas tiene su peso. La Educación para la Solidaridad y la Educación para la Interioridad tienen un $40 \%$ del peso de la asignatura. Entre las dos, un $80 \%$. Y el $20 \%$ restante es cultura-religiosa» (E2/IZ.2_1).
} 
hainbat jarrera eta portaera ikasiz eta esperimentatuz» (D/PES. 6_4) 3 . Horretarako hiru galdera oinarritzat hartzen dituzte: «Nor da bestea?» (D/ PES. 8_3) «Zer eragiten du besteak nigan?» (D/PES. 9_3) «Zer egiteko prest nago bestearen alde?» (D/PES. 10_3 $)^{4}$.

Ideia horietatik abiatuz, hortaz, PES proiektua astero burutzen dela dio elkarrizketatuak; bi alderditan banatzen dela adieraziz: alderdi praktiko bat eta alderdi teoriko bat, hain zuzen. Zehazki, PES proiektua honela burutzen dela dio: «PES astero da, ordutegitik kanpokoa delako. Beno, (...) alderdi teorikoa, esan dezagun, ikasgelan egiten dugula, baina alderdi praktikoa eskola-ordutegitik kanpo burutzen da» (E2/IZ. 3_7 $)^{5}$. Alderdi teorikoa lantzeko tarteaz honako hau adierazten du parte-hartzaileak: «Ordu hori asterokoa da, aurrez aurrekoa, ikasgelan izaten da beti, hamarretatik hamaiketara bitartean. (...) Eta ordu horretan (...) PESen alderdi teorikoa jorratu, Barnekotasunaren atal teorikoa edo prestaketarena burutu eta egun batzuetan erlijio-kulturaren curriculuma lantzeko aprobetxatzen dugu» (E2/IZ. 4_1)

PES proiektuaren atal praktikoari dagokionez, elkarteetako ordutegiekin bateratzeko dauden zailtasunen ondorioz, hori eskola-orduz kanpo burutzen dela dio elkarrizketatuak. Horretarako, ikasgai horrek biltzen duen beste ikastordua elkarteetan burutzen duten saio horrekin ordeztu dute: «Orduan, noski, zentzu horretan oso ondo datorkigu (...) ostiraleko ordu presentzialetako bat, ordu-bietatik hirutarakoa, ordezkatu egiten da, ikasgelan presentziala dena elkartean presentziala denarekin ordezkatzen da, baina ez dute zertan ... ordutegi horretan egin (...)». (E2/IZ. 3_7)»7.

Hortaz, aipatutakoa kontuan izanik, proiektu horren partaide diren Batxilergoko ikasleak ikasturteko aste orotan elkarte batera joaten direla dio elkarrizketatuak. Horretarako, adinez gutxikoak direnez, hezkuntza komunitateko edozein helduren laguntza jasotzen dute (irakasle, ikasle zein familiakide ohi edota familiak). Laguntzaile horiei dagokienez, gehienetan

3 «El conocimiento la sensibilización y el compromiso del alumnado con las distintas realidades sociales existentes en el entorno en el que viven, a través del aprendizaje, y experimentación de diferentes actitudes y comportamientos» (D/PES.6_4)

4 «Quién es el otro?»(D/PES. 8_3) «¿Qué despierta el otro én mí?»(D/PES. 9_3) «QQué estoy dispuesto a hacer por el otro?»(D/PES. 10_3).

5 «El PES es todas las semanas porque es fuera de horario. A ver, (...) la parte teórica, digamos, la hacemos dentro del aula, pero la parte práctica es fuera del horario escolar» (E2/IZ. 3_7).

6 «Esa hora que es semanal, presencial, (...) siempre es en clase, que es de diez a once. (...) Y en esa hora es cuando aprovechamos para (...) la parte teórica del PES, la parte teórica o de preparación de la Interioridad y algunos días con el tema del currículum de cultura religiosa» (E2/IZ.4_1).

7 «Entonces, claro, en ese sentido nos viene muy bien porque una de las horas presenciales que es la del viernes de dos a tres se sustituye, se sustituye lo presencial en el aula, por lo presencial en el centro, pero no tienen por qué cursarla en ese... en ese horario «(E2/IZ. 3_7). 
era boluntarioan beren burua eskaintzen duten helduak izaten direla dio parte hartzaileak; are gehiago, oro har, boluntariotzaren gaiarekin lotura duten profilak izan ohi direla zehazten du. Horiek parte hartu nahi duten ekimena libreki hautatzeko aukera izaten dute: «Normalean, helduak eskaintzen dira (...). Bai... pertsona heldua guztiz boluntarioa da; orduan, pertsona helduak bere burua eskaintzen $d u$, (...) eta beno, jakina, ibilbide luzeko jendea izaten da, boluntariotza gaietan eta horrela... Bai, gizarte-arloaren berri duen jendea» (E2/IZ. 10_4) ${ }^{8}$. Halaber, familia gehiago proiektu hauetan inplikatzeko ate irekiak burutzen dituztela dio elkarrizketatuak.

Aitzitik, proiektua gidatzen duen arduradunari dagokionez, ikasgaiko irakaslea dela dio elkarrizketatuak, nahiz eta ikasleen proposamenetara irekia egon. Izan ere, parte-hartzaileak hauxe adierazi du: «Errubrikan badago zati bat: zenbaterainoko proaktiboa naiz praktikan; esaten didatena edo proposatzen dudana egiten dut?; proposatzailea naiz?» (E/IZ. 39_9) ${ }^{9}$. Errubrikari erreparatuz gero, adituak adierazitakoa baieztatzen da; «Praktikan izandako inplikazioa» (D/PES.ERRUBR.) ${ }^{10}$ hainbat irizpideren baitan neurtzen baita.

Ildo beretik, ikasleen iniziatiba hori azaltzeko adibide bat partekatu du azterketako protagonistak: «Izan ere, beti diot. Duela bi urte Portugaleteko kirol nautikoarekin hasi ginen igeriketa inklusiboan, bi ikaslek ibilbide oso luzea zeramatelako igeriketan eta ondoren igeriketa sinkronizatuan, eta haiek esan zidaten, aizu, badago talde bat, premia bereziak dituzten pertsonentzat... Igeriketa egokitua da. Zergatik ez diegu laguntzen? Arduradunarekin hitz egin nuen eta oso ondo iruditu zitzaion» (E/IZ. 39_13). «Eta baditugu astero proiektu horretan parte hartzen duten ikasleak eta poz-pozik daude. Eta haiengandik jaio zen, nik ez nuelako ezagutzen agian ingurua...» (E/IZ. 39_15). «Edo asko ezagutzen dut, baina agian alderdi hori ez nuen buruan» (E/IZ 40_1) ${ }^{11}$. Ondorioz, kasu horretan, garrantzi handia ematen zaio ikaslearen iniziatibari; ikasleen

8 «Normalmente el adulto, los adultos se ofrecen (...). Si... la persona adulta es totalmente voluntaria; entonces la persona adulta se ofrece, (...) y a ver, evidentemente suele ser gente con mucho recorrido, en temas de voluntariado y así... Sí gente que tiene conocimiento de lo social (...)» (E2/IZ. 10_4).

9 «Hay una parte en la rúbrica que tienen que es ¿Cuánto de proactivo soy en la práctica?; ¿Hago lo que me dicen o propongo?: ¿Soy propositivo?»(E/IZ.39_9).

10 "Implicación en la práctica» (D/PES.ERRUBR.)

11 «De hecho, siempre lo digo también. Hace dos años empezamos con la deportiva náutica de Portugalete en el tema de natación inclusiva porque había dos alumnas de clase que llevaban una trayectoria súper larga en el tema de natación y luego en la natación sincronizada y fueron ellas las que me dijeron, oye, e... hay un grupo para personas pues con... necesidades especiales y tal. Es un tema de natación adaptada. ¿Por qué no echamos una mano nosotras en eso? Hablé con la responsable, le pareció súper bien» (E/ IZ. 39_13). «Y tenemos alumnos todas las semanas y alumnas que participan en ese proyecto y están encantados y encantadas. $Y$ nació de ellas, porque yo no conocía el entorno 
proposamenen bitartez ere proiektu berriak abiaraz daitezkeela adierazten baitu parte hartzaileak.

Halaber, hasiera batean elkarteekin ezarritako loturak irakaslearen bitartez lortu zirela onartzen du irakasleak. Orokorrean, haiekin kontaktua ezartzea haren egitekoa dela baietsi zuen.

Bestetik, praktika horiek ikasmaila zehatz horietan burutzeari arreta ezarriz gero, lehenengo Batxilergoa praktika solidarioak burutzeko momentu aproposa dela adierazten du elkarrizketatuak; hurrengoa esaten baitu: «Gu ziur gaude ikaskuntza lehenago egin behar dela» (E/IZ. 43_13) «lehenago deskubritu behar da» (E/IZ. 43_15) ${ }^{12}$. Unibertsitatera heldu aurreko azken bi urteak esperientzia mota horien bitartez konpromisoa lantzeko adin egokiak direla azalduz. Horrez gain, praktika solidarioak burutzeko gutxieneko adin bat izatea ere ezinbestekoa dela adierazten du, Batxilergoa horrelako esperientzia bat aurrera eramateko etapa perfektua dela esanez: "Adina garrantzitsua da, ez digutelako uzten (...). Zentro jakin batzuetan 16 urtetik beherakoekin oso zaila izaten da. Orduan, nolabaiteko heldutasuna eskatzen du, nolabaiteko ibilbidea eskatzen du eta egoten jakitea, ezagutza jakin batzuk eskatzen ditu, noski, eta nire ustez oso garrantzitsua da Batxilergoan kokatuta egotea (...)» (E2/IZ. 16_1 $)^{13}$.

Atal honekin amaitzeko, ikasgai horren ebaluazioari dagokionez, lehenik eta behin, Batxilergoko gainontzeko ikasgaiek bezalako balioa duela adierazten du parte hartzaileak. Horrez gain, azken ebaluazioa osatzeko ezartzen den kalifikazioa irakaslearen esku geratzen den arren, hura osatzeko ikuspuntu ezberdinak jasotzen direla azpimarratzen du, hala nola, ikaslearena, laguntzaileena eta elkarteko kideena. Lehenengo biek errubrika baten bitartez ebaluatzen dute esperientzia. Emaitza oso baikorrak eskuratzen direla adierazten du parte-hartzaileak: «Esperientzia beti ebaluatzen da, familiek ebaluatzen dute, normalean 8tik gora egoten da. Orduan, beno, ebaluazio oso ona jasotzen duen praktika bat da, eta neska-mutikoen artean gogobetetasuna sortzen du, uste dut balorazioa gutxi gorabehera 7 eta 8 artean dagoela (...)» (E2/IZ. 11_1) ${ }^{14}$.

quizás de...»(E/IZ.39_15). «O sea conozco mucho, pero o sea igual esa parte no la tenía en mente» (E/IZ.40_1).

12 «Nosotros estamos convencidos de que hay que hacer el aprendizaje antes» (E/IZ. 43_13) «hay que descubrirlo antes» (E/IZ.43_15).

${ }_{13}$ «La edad es importante porque no nos permiten (...). Con los menores de 16 años en determinados centros es muy complicado. Entonces, exige cierta madurez lógicamente, exige cierto recorrido y saber estar, exige ciertos conocimientos, por supuesto, y yo creo que es muy importante que esté situado en Bachillerato (...)»(E2/IZ. 16_1).

14 «La experiencia siempre es evaluada, es evaluada por las familias (...) normalmente está por encima del 8. Entonces, bueno, es una práctica que suele estar muy bien evaluada, (...) y suele crear satisfacción entre los chavales creo que está en un 7 bastante alto (...)» (E2/IZ. 11_1). 
Errubrikari dagokionez, bost aspektu dira bertan aztertzen direnak (D/ PES.ERRUBR.): asistentzia, praktikan izandako inplikazioa, pertsonekiko adierazitako konpromisoa, talde-lana, eta ikaskuntzarako zein bizitzarako eskuratutako ekarpenak. Hortaz, aipatutako bost irizpide horietan oinarriturik ikasle zein laguntzaileek ikaslearen parte hartzea ebaluatzen dute. Horretarako, batetik hamarrerako balioa ezarriz. Horrez gain, ebaluazioa errazago egiteko irizpide horiek sakonago azaltzen dira aipatutako dokumentu horretan. Bestetik, esperientziaren inguruko ekarpenen bat egiteko espazioa ere eskaintzen zaie ikasle zein laguntzaileei.

Elkarteko kideen ebaluazioari erreparatuz gero, haien iritzia jasotzea beharrezkoa dela dio parte-hartzaileak. Izan ere, hauxe adierazten du: «Elkarte bakoitzeko itxiera eta ebaluazio bat egin ohi dugu, eta, ondoren, aitorpena burutzen dugu, jai-giroan diplomak banatuz. Orduan bai, beti egiten dugu balorazio bat; baita elkarteetako arduradunek ere. Guk gizarteari buruzko inkesta deitzen den gauza bat dugu, eta elkarteetako arduradunek PES horrekin ebaluatzen dute. Eta horrek ere, nota oso altua izaten $d u$, oso ondo dago, iradokizun oso interesgarriak helarazten dizkigutelako» (E2/IZ. 12_3 $)^{15}$.

\subsection{Irakasle-ikasleen harremanetan onurak}

Proiektu hauen bitartez eskuratzen diren harremanei arreta jarriz gero, hainbat dira eskola-komunitatea osatzen duten pertsonek jasotzen dituzten onurak. Lehenik eta behin, irakasle-ikasleen arteko harremanak hobetu egiten direla adierazten du adituak. Izan ere, arestian aipatu bezala, irakasleak ikaslearekiko beste ikuspegi bat eskuratzen du proiektu hauen bitartez. Parte-hartzaileak honako hau dio: «Ikaslea, nire ustez, esperientzia horien bitartez gaituago sentitzen da, eta irakasleak ere hau ikusten du; beraz, harreman hori hobetu egin daiteke. (...) Zu ez zaren edo berdinak ez diren beste pertsona batzuekin harremanetan jartzen duzunean, haien ahalmenez ohartzen zara»(E/IZ.41_5) ${ }^{16}$.

15 «Solemos hacer un cierre y una evaluación por cada centro y luego hay un reconocimiento general de entrega de diplomas en un ambiente más festivo (...). Entonces sí, si hacemos siempre una valoración y de hecho los responsables del centro también. Nosotros tenemos una cosa que se llama encuesta de sociedad y con él los responsables de los centros evalúan el PES. Y también suele tener una nota muy alta, lo que pasa es que está muy bien, porque nos hacen llegar algunas sugerencias muy interesantes (...)» (E2/IZ. 12_3).

16 «El alumno y la alumna yo creo que con esas experiencias se vive o se descubre más capaz, el docente también con lo cual esa relación también puede mejorar. (...) El problema es cuando le pones en relación con otra gente que no eres tú o que no son sus iguales también te das cuenta de sus potencialidades» (E/IZ.41_5). 


\subsection{Ikasleen harremanetan onurak}

Ikasleen arteko harremanei dagokienez ere, irakasleei gertatzen zaien modura, ikasleek ere haien ikaskideekiko beste ikuspegi bat garatzen dutela adierazten du azterketako elkarrizketatuak: «Ba, begira, nik esango nizuke kasu batzuetan baietz, bai. Hau da, proiektua agian ez doa horretara bideratuta, baina azkenean taldea egin behar dute (...). Orduan, asteroko talde lan bat denez, beste ikasgela batzuetako kideekin harremanetan jartzen zara (...). Horrek beste modu batean ezagutzen laguntzen dizu. (...) Beraz, beste testuinguru batzuetan elkar topatze zein deskubritze hori oso garrantzitsua da neska-mutilentzat, eta laguntza-testuinguru batean, batzuetan sorpresak izugarriak dira guztiontzat» (E2/IZ. 18_3) ${ }^{17}$. Horrez gain, proiektu hauen bitartez adin ezberdineko ikasleak harremanetan egoten direnez, senidetasun modukoak burutzen direla dio partehartzaileak.

\subsection{Familien eta eskolaren harremanetan onurak}

Familiei dagokienez, haiek proiektuetan parte har dezaketela aipatzen du parte-hartzaileak. Batxilergoan, esaterako, haiek dira proiektu ezberdinetan parte hartzen duten elkarteetara laguntzen dieten arduradunetako batzuk. Horrez gain, elkarrizketan zehar hainbatetan esan bezala, ugariak dira ekimen hauen ondorioz eskolarekin kontaktatzen duten familiak, beren seme-alabak bizitzen ari diren prozesu horrek eragindako poztasuna partekatzeko. Horren adibide da eskolako ama batek bere semeak ikasitakoaren inguruan irakasleari idatzitakoa: «Begira, bere amak kontatu zigun (e-mail bat idazteko keinua)»(E/IZ. 44_7). "Bere ama harrituta zegoen, erabat harrituta.Orduan hori da ideia, ezta?» (E/IZ.44_9).18

\subsection{Ikasleen eta komunitatearen harremanetan onurak}

I-Zren bereizgarria den ingurunearekiko harremanari dagokionez, esperientzia horiek guztiek errealitate sozial ezberdinen inguruko aurreiritziak

17 «Pues mira, yo te diría que en algunos casos sí, sí. O sea, es verdad que el proyecto igual no va enfocado a eso, pero al final tienen que hacer grupo (...). Entonces, al ser grupal semanalmente estás relacionándote con compañeros de otras clases (...). Te ayuda a conocerlos de otra manera. (...) Entonces, eso es muy importante también para los chavales que se vean, que se descubren en otros contextos y en un contexto de ayuda a veces las sorpresas son enormes para todos» (E2/IZ. 18_3).

18 «Mira, nos lo contaba su madre (gesto de escribir un email»(E/IZ.44_7). «Su madre alucinaba, su madre alucinaba. Entonces esa es la idea, ¿No?» (E/IZ.44_9). 
deuseztatzen laguntzen dutela dio elkarrizketatuak. Zehatzago esanda, ikasleek inguruko errealitateei buruz dituzten aurreiritziak, eta inguruak gaur egungo gazteei buruz dituzten aurreiritziak lantzeko modu aproposa dela dio parte-hartzaileak: «Hartzaileei, inguruari, beno, nik uste dut aurreiritzi ugari ezabatzen asko laguntzen duela, gazteei buruz, gazteen munduari buruz, ezta?» (E/IZ.29_18). «(...) Zer egiteko gai dira haurrak? (...) Pff? (Besoak zabalduz) «(E/IZ. 29_20) ${ }^{19}$.

Ikasleek errealitate sozial ezberdinen inguruan dituzten aurreiritziei dagokienez, Batxilergoko ikasle bati gertatutako pasarte bat partekatzen du alderdi hori azaltzeko: «Gogoan dut Aspacen, garun paralisia duten pertsonekin elkartuta zegoen ikasle batek esan zuena, ezta? -Ni gurpildun aulkiak ikusten hasi nintzen, ez nintzen pertsonak ikusteko gai, inoiz ez nuen horrelako errealitaterik izan etxean, ez nekien. Nire aitona-amonak gazteak dira. -Oso hunkituta esaten zuen-Nik ez nekien zer zen gurpildun aulkian zegoen pertsona bat, Aspacera iritsi nintzen arte, iritsi eta aulkia ikusteko gai baino ez nintzen, eta niretzat oztopo bat zen (...). Ez nintzen gai.... aulkia ikusten nuen eta...»-eta proiektuaren amaieran esaten du- (...)»(E/IZ. 42_9). «-Ekaina bukatu dut pertsonak ikusten, nik ez dut gurpildun aulkirik ikusten (...) gainera, nik...ez nekien aulki hori maneiatzen..., - eta esaten du- eta pertsonak ikusten amaitu dut» $\left(\mathrm{E} / \mathrm{IZ} .43 \_1\right)^{20}$.

Horrez gain, harreman horien bitartez jaiotzen den ikaskuntza-prozesu hori bizitzaren isla dela dio elkarrizketatuak. Izan ere, nagusiekin horrelako esperientziak burutzean, haiek egiten dituzten galderei erreferentzia eginez, hurrengoa dio elkarrizketatuak: «Nagusiengan pentsatzen ari naiz, $e$ ? Baina zer erakutsiko diegu bada guk gazteei, ezta? (Klaskada) Alde batera utzi ideia hori. Kanpora, noski erakusten diezuela, noski beraiek ikasten dutela, eta noski zuek haiengandik ikasten duzuela. Orduan, diluitu egiten da, hau da, nork ikasten du norengandik? Hau da, nork eta nori irakasten dio? (...)» (E/IZ. 30_3). «Bizitza da» (E/IZ. 30_8). «Hori da, ikaskuntza

19 «A los receptores, al entorno, bueno yo creo que ayuda mucho a eliminar muchos prejuicios, sobre el mundo de los jóvenes ¿No?»(E/IZ.29_18). «(...) ¿De qué son capaces los niños? (...) Pff... (Ampliando los brazos)»(E/IZ. 29_20).

20 «Yo... me acuerdo también de un alumno que en Aspace que es una asociación con personas con parálisis cerebral, como decía ¿No? -yo empecé viendo sillas de ruedas, no era capaz de ver a las personas, nunca había tenido una realidad así en casa, desconocía. No había visto jamás, mis abuelos son jóvenes...-O sea lo decía súper emocionado-Yo no sabía lo que era una persona en silla de ruedas, hasta que llegué a... Aspace (...) y no era capaz más que de ver la silla, y era para mí un oztopo (...). No era capaz de... veía la silla y era ... - y dice al final del proyecto- (...)»(E/ IZ. 42_9). "-He acabado junio viendo a las personas, yo no veo una silla de ruedas (...) porque además yo... no sabía manejarla... $-y$ dice $-y$ he acabado viendo a las personas» (E/IZ. 43_1). 
guztiz naturala, beharrezkoa, espontaneoa eta... eta... bai, beharrezkoa da, bai...»(E/IZ. 30_9 $)^{21}$.

\subsection{Eskola eta komunitatearen harremanetan onurak}

Hori dela eta, ezartzen diren harreman horien guztien bitartez, inguruak eskolari eta alderantziz eskain diezaiokeen potentzialaz ohartzen laguntzen dietela dio parte-hartzaileak. Horrela, Portugaleten Santa Maria ikastetxea posizio esanguratsuan kokatzen du. Izan ere hurrengoa dio: «Hezkuntzakomunitatea eta, batez ere, zuzendaritza-taldea edo ikastetxea, niretzat hor kanpoan jartzen dituzte, nik esango nuke. Izan behar dugun horretan jartzen du arreta zentroak, eta are gehiago kristau ekimen sozialeko eskola batean (...)» (E/IZ. 33_7 $)^{22}$.

Bestalde, proiektu horiekin, eskola ere ezagunagoa bihurtu dela onartzen du; izan ere, proiektu horiek ezagutaraztearen ondorioz, elkarrizketatuak dioenez, inguruko eskola batzuk I-Zko metodologia aurrera eramaten hasi dira. Are gehiago, zabalkuntza horretan Santa Maria ikastetxeak bere egitekoa izan duela adierazi du: «Jende asko formatu dugu. Formakuntzak burutzeko deitu digute» (E/IZ. 38_18) ${ }^{23}$. Formakuntza horiek kristau-eskolen sarean ez ezik, Berritzeguneetan ere eman dituzte. Gainera, Batxilergoko esperientzian oinarrituz, proiektu berdinean parte hartzen dutengainontzeko ikastetxeekin topo egiten dutela esaten du elkarrizketatuak. Areago ikastetxe ezberdinetako ikasleen arteko harremanak bermatzen direla adierazten du.

Azkenik, hainbat hilabetez mantendu izan den harreman horren ondorioz, ikasle askok Batxilergoa amaitu ostean proiektu horretan modu boluntarioan jarraitzen dutela adierazten du: «Eta gero loturak sortzen dira; izan ere, imajinatu urtean 90, 99 neska-mutil ingurutik... 20 bat gaztek modu boluntarioan jarraitzen dutela» (E/IZ.43_7). «Beraz, oso proportzio adierazgarria da, oso adierazgarria zentzu horretan. Hau da, 100 ikasletik 20 eta koska» (E/IZ.43_9 $)^{24}$.

21 «Estoy pensando en los mayores ¿E? Hija, pero que les vamos a enseñar nosotros a los jóvenes ¿No? (Chasquido) fuera esa idea. Fuera, claro que les enseñáis claro que ellos aprenden y claro que vosotros aprendéis de ellos y de ellas. Entonces, o sea se diluye o sea ¿Quién aprende de quién? O sea ¿Quién enseña a quién? (...)» (E/IZ. 30_3). «Es que es la vida» (E/IZ. 30_8). «Eso es, es que es un aprendizaje absolutamente natural, necesario, espontáneo y que...y que... sí es imprescindible sí... «(E/IZ. 30_9).

22 «La comunidad educativa y sobre todo el equipo directivo o el centro educativo, para mí los ponen ahí fuera. Pone el centro el foco en lo que estamos llamados a ser y más una escuela de iniciativa social cristiana (...)»(E/IZ. 33_7).

23 «Hemos formado a mucha gente. Nos han llamado para formar» (E/IZ. 38_18).

24 «Y luego se crean vínculos, pues de... imagínate de un alumnado de unos 90, 99 chavales al año hay un grupo de unos 20 tantos que continúan de forma voluntaria» (E/IZ. 43_7). "Entonces es una proporción muy maja, muy maja en ese sentido. O sea, de 100 alumnos 20 y pico» (E/IZ. 43_9). 


\subsection{Eskola eta komunitatearen harremanetan mugak}

Harremanetan agertzen diren zailtasunei dagokienez, gazteen adinak, eta herritarrek gazteekiko izan ditzaketen ezjakintasunak eragindako mugak aipatzen ditu elkarrizketatuak. Gazteen adinari erreparatuz gero, hasiera batean elkarteen aldetik hainbat oztopo egon zirela onartzen du, laguntzaileen funtzioak muga horiei aurre egiten lagundu zuela esanez: «Elkarte batzuek oztopo ugari jarri zizkiguten hasieran, orain ez hainbeste oso ezaguna delako, baina hasieran beraiek ere oztopo asko jartzen zituzten adinaren gaiarekin. Badakizu, batzuetan, 18 urte bete arte, ez da posible. Orduan, nolabaiteko heldutasuna nahi zuten, egoten jakite hori, alegia. Egia da taldean lagunduta doazenez, hori guztia ere zaindu egiten dela (...)» (E2/IZ. 16_3 $)^{25}$.

Bestetik, inguruaren ezjakintasunaren ondorioz egon daitezkeen beldurrak aipatzean, horiek konponbide erraza dutela adierazten du: "Ingurunea, ezezagunarekiko beldurra. Ezagutu bezain laster, beraiek deitzen digute ateetara. Aizu, jakin dugu Santa Marian horrelako praktikak egiten dituzuela, aizu, datorren urterako zuekin konta genezake? Zoragarria da, ezagutzen ez denaren beldurra da, baina behin jakiten denean, jakiten denean arazorik gabe joaten gara» (E/IZ. 38_14 $)^{26}$.

\section{ONDORIOAK}

I-Zren munduan 22 urtez lanean jardun duen eta, egun, horren hobetze prozesuko eginbidean jarraitzen duen Portugaleteko Santa Maria ikastetxearen kasua topatu eta aztertu ostean, hainbat dira lan honetan eskuratu diren ondorio eta hausnarketak.

Lehenik eta behin, aipatutako ikastetxeko Batxilergoko I-Z esperientzia bat ezagutzea lortu dela esan daiteke, PES proiektua, hain zuzen. PES duela lau urte Batxilergo etapako curriculumaren parte da. Zehatzago adierazita, proiektu hori biltzen duen ikasgaia Batxilergoko lehenengo urtean derrigorrezkoa da, eta bigarrenean, berriz, Unibertsitatera Sartzeko Ebaluazioa dela medio, hautazko gisa eskaintzen da. Horrez gain, ikasgai hori

25 «Hubo centros que nos pusieron muchas pegas al principio, ahora ya no tanto porque ya es muy conocido, pero al principio ellos ponían muchas pegas con el tema de la edad también. Ya sabes que a veces hasta los 18 no es posible. Entonces bueno, pues querían cierta madurez, ciertos, saber estar. Es verdad que como en el grupo van acompañados, todo eso también se cuida (...)»(E2/IZ. 16_3).

26 «El entorno, pues el miedo a lo desconocido. Alguna vez que lo conocen es que ya te digo nos llaman ellos a las puertas. Oye, es que nos hemos enterado que, en Santa María hacéis este tipo de prácticas, oye, el año que viene ¿Podríamos contar con vosotros? Es una maravilla, es el miedo a lo que no se sabe, pero una vez que se sepa, una vez que se sabe vamos sin problema» (E/IZ. 38_14). 
beste hainbeste ikaskuntza lantzeko ere erabiltzen dela egiaztatu da, hala nola Barnekotasunerako Hezkuntza eta erlijio-kultura. Baina, aipatzekoa da, ebaluazioari begira, haren balioa gainontzeko ikasgaien bera dela. Hortaz, Batxilergoaren kasuan, Santa Maria ikastetxea askotariko ikasgaiak parekatzera iritsi dela ondoriozta daiteke. PES proiektura itzuliz, hortaz, literaturan Puig et al.-ek (2007) adierazi bezala, ulertu da hori ikasleek errealitate sozial ezberdinen inguruko ezagutza, sentsibilizazioa eta konpromisoa lantzeko burutzen den proiektua dela.

Ikerlan honen helburu nagusiari helduz, I-Zren bidez Santa Maria ikastetxeko hezkuntza komunitateko eragileen artean sortzen diren harremanak aztertzea lortu dela esan daiteke. Are gehiago, onura horiek hezkuntza-komunitateko kide bakoitzari ezberdin eragin diezaioketela ikusi da.

Lehenengoz, ikasgela barnean loratzen diren harremanei erreparatuz gero, irakasleei dagokienez, haientzat ere, proiektu hauek burutzea arnasaldi bat dela behatu da. Proiektuen bitartez, ikasleen inguruko beste ikuspuntu bat lortzen baitute. Zehatzago esanda, ikasleak beste testuinguru batzuetan nola moldatzen diren behatzean, haien inguruko ezagutza integralagoa eskuratzen dute. Aipatutako horrek ikasle eta irakasleen artean loratzen diren harremanekin lotura garbia du. Izan ere, ikaslea praktika horietan gaituago sentitzen denez, irakasleak ere hori ikusten duela ulertu da. Ondorioz, balioztatze bikoitz horretan, haien arteko harremana hobetzen dela ikusi da. Esandakoa, hortaz, Batlle-k (2013) ikasleengan garatzen den auto-estimuaren ideiarekin lotu daiteke. Ikasleak gaituago sentitzean, indartze pauso horrekin batera, ikasgelako klima ere hobetu egiten baita.

Irakasle-ikasle artean loratzen diren harremanekin jarraituz, lotura horizontalak direla azpimarratzekoa da (Serrano eta Ochoa, 2019). Izan ere, ikaskuntzak proiektuko partaide ororen artean eraikiz doazenez, irakasleak bere lidergo-rol hori alde batera uzten du, norabiderik gabeko ikaskuntzak bultzatuz eta protagonismo hori proiektuko kideen artean banatuz.

Ikasleen artean garatzen diren harremanei dagokienez, proiektu hauen bitartez, beste geletako ikasleekiko harremanak ezarri ez ezik, beste egoera batzuetan ezagutzera heltzen direla egiaztatu da. Horrek guztiak ere ikasleen arteko loturak indartzen dituela ondorioztatu da. Honenbestez, Ikaskuntza-Zerbitzua eskolaz barneko zein kanpoko adin ezberdineko kideak harremanetan jartzeko metodologia aproposa dela behatu da (Batlle, 2011).

Bestalde, I-Zk biltzen duen alderdi gizatiarrari erreparatuz, ikasleak giza talde ezberdinekin harremanak izatearen bidez, gazte zein haurrek giza talde zehatzekiko, zein alderantziz, izan ditzaketen aurreiritziak deuseztatzen direla ikusi da. Izan ere, literaturan adierazi bezala, I-Zren bidez, haur, gazte, heldu zein adinekoen artean egon litezkeen aurreiritzi edo ideia desegokiak gainditu eta harreman sendoagoak loratzen dira (Batlle, 2011). Hori pertsona talde ezberdinen arteko harremanak loratu ahal izateko beharrezko pausoa izanik. Hortaz, harreman horiek bermatzea ezinbestekoa delako ondoriora iritsi da. Azken finean, kontaktua ezartzean, on- 
doren loturak sortzea errazagoa baita. Modu horretan, ikasle zein elkarteen artean ondoren modu boluntarioan mantenduko diren lotura nabarmenak eraikiz. Hortaz, kasu horretan ere, Puig et al.-ek (2007) adierazitakoa betetzen dela esan daiteke. Izan ere, autore horien aburuz, I-Zren bidez herritarrak sentsibilizatu ez ezik, haien eskutik laguntza gehiago jasotzeko aukera areagotzen da.

Horrez gain, familiei dagokienez, honakoen parte hartzearen bitartez, eskolarekin duten harremana hobetu daitekeela egiaztatu da, proiektu hauen inguruko feedback-ak itzultzeko eskolarekin kontaktuan jartzen baitira. Hortaz, Batxilergoko ikasleen familiak haien ikaskuntza prozesura gerturatzeko modu egokia dela esan daiteke. Halaber, hezkuntza eragile horiek esperientzia ezberdinen partaide izatea oso baikorra den arren, oro har laguntzaileen profil bera errepikatzen dela ikusi da. Hortaz, familiako kideek izan ditzaketen esperientzia zein formakuntza kontuan izan gabe, parte-hartze anitzagoa bilatu nahi dela ere onartu da. Horretarako, PES proiektura guraso gehiago gerturatzeko ate irekiak burutzen dituztela frogatu da.

Halaber, parte-hartze urri hori familiek izaten duten beldurrarekin lotu daiteke. Hortaz, kezka horiek gainditzeko, Montes et al.-ek (2011) adierazi bezala, beharrezkoa litzateke komunitatea eta eskolaren arteko loturaren garrantzia zein den erakustea. Bestetik, komunitateko kide orok proiektua ongi ezagutu beharko du (Montes et al., 2011).

Azkenik, I-Zk Santa Maria ikastetxeko Batxilergoko etapan eskola-komunitate harremanean zenbait muga identifikatzea lortu dela ere esan daiteke. Metodologia horren aplikazioaren bitartez Batxilergoko mailan sortzen diren harremanetan onura ugari identifikatu diren arren, oraindik ere, praktika horiek martxan jartzean zenbait oztopo topa daitezkeela ikusi da. Ekimen horiek burutzeko, heldutasun maila bat exijitzeaz gain, Batxilergoko gazteekiko zenbait aurreiritzi daudela egiaztatu baita. Halaber, aipatutako proiektuetan murgiltzean muga horiek segituan desagertzen direla ikusi da.

Lanarekin amaitzeko, ikerlan honetatik loratutako hainbat hausnarketa partekatu nahi dira. Izan ere, Batxilergoan onura ugari aurkezten dituen metodologia bat ezagutu den arren, erronka gisa uler daitezkeen hainbat alderdi topatu direla onartu behar da. Zehazki, metodologia hau ikasmaila gehiagotara zabaltzea I-Zk egun izan dezakeen erronka gisa ikusten da. Izan ere, Hezkuntza Sistemak berak duen egituraren ondorioz, etapa horretan metodologia horren guztizko apustua egitea zaila dela ulertu da. Azken finean, sistemak berak eragiten dituen presioei aurre egiteko modua, neurri handi batean, egitura tradizionala mantentzea baita. Hala ere, apurkaapurka ikuspegi hori zabaltzea aurrerapauso handia dela esan daiteke, eta horretan jardun behar dela sinesten da. Ikastetxe honetan, erlijioaren bidetik bideratu bada ere, neurri batean, metodologia tradizionalei aurre egitea lortu da. 
Hortaz, zabalkuntza horretan, metodologia horren inguruko informazioa hedatzeak garrantzi handia duela sinesten da. Are gehiago, Batlle-k (2013) aipatu bezala, I-Z berraurkikuntza metodologiko bat izanda, ikastetxe askotan jada burutzen den praktika ezezaguna izan litekeela uste da. Hortaz, hori ezagutzera emanez gero, ugariak izan daitezke metodologia honetako irizpideei jarraikiz aurkitu zein sortu litezkeen proiektu aberatsak. Egiteko horretan, metodologia horren inguruko formakuntzak ezinbesteko bilakatzen dira. Zehaztearren, Berritzeguneetako saioak ez ezik, unibertsitate zein beste eremutatik burutzen diren topaketa, hitzaldi, eta abarrek ere egiteko ugari izango dute. Orobat, metodologia horren baitan burutzen diren esperientziak gorde zein ezagutarazten lagunduko duen ikerketaren arloak ere.

\section{ERREFERENTZIA BIBLIOGRAFIKOAK}

Abela, J. A. (2002). Las técnicas de análisis de contenido: una revisión actualizada. Fundación Centro de Estudios Andaluces.

Bardin, L. (1996, 2. edizioa). Análisis de contenido. Akal.

Battle, R. (2011). ¿De qué hablamos cuando hablamos de Aprendizaje-Servicio?. Rítica, 972, 49-54. or. http://roserbatlle.net/wp-content/uploads/2012/02/deque-hablamos-cuando-hablamos-de-aps-revista-crc3adtica1.pdf

Batlle, R. (2013). El aprendizaje y servicio en España: el contagio de una revolución pedagógica necesaria. $\mathrm{PPC}$.

Batlle, R. (2020). Aprendizaje-Servicio. Compromiso social en acción. Santillana.

Billig, S. H. (2000). The Effects of Service Learning. Service Learning, General, 42. http://digitalcommons.unomaha.edu/slceslgen/42

Billig, S. H. (2002). Support for K-12 service learning practice: A brief review of the research. Educational Horizons, 80, 184-189. or. https://www.jstor.org/ stable/42927126?seq=1

Bisquerra, A. (2004). Metodología de la investigación educativa. La Muralla.

Bolívar, A. (2006). Familia y escuela: dos mundos llamados a trabajar en común. Revista de Educación, 339(1), 119-146. or. http://ibdigital.uib.es/greenstone/ collect/portal_social/index/assoc/miso1089/4_002.dir/miso10894_002.pdf

Del Rincón, D., Arnal, J., Latorre, A., eta Sans A. (1995). Técnicas de investigación en ciencias sociales. Dykinson.

Echeverría, G. (2005). Análisis cualitativo por categorías. Apuntes docentes, Universidad Academia de Humanismo Cristiano. https://www academia. edu/9444115/Apuntes_Docentes_de_METODOLOGIA_DE_INVESTIGACION_ANALISIS_CUALITATIVO_POR_CATEGORIAS

Furco, A. (1996). Service-Learning: A Balanced Approach to Experiential Education. Expanding Boundaries: Serving and Learning, 2-6. https://digitalcommons.unomaha.edu/slceslgen/128/

Herrera, K., eta Rico, R. (2014). El clima escolar como elemento fundamental de la convivencia en la escuela. Escenarios, 12(2), 7-18. or. https://doi. org/10.15665/esc.v12i2.311 
Karrera, I. (2008). El método cualitativo como herramienta válida en la resolución de conflictos. UPV/EHU.

Martínez-Odía, A. (2007). Service-learning o aprendizaje-servicio: la apertura de la escuela a la comunidad local como propuesta de educación para la ciudadanía. Bordón. Revista de pedagogía, 59(4), 627-640. or. https://dialnet.unirioja. es/servlet/articulo?codigo $=2582784$

Mendia, R. (2012). El aprendizaje-Servicio como una estrategia inclusiva para superar las barreras al aprendizaje y a la participación. Revista de Educación Inclusiva, 5(1), 71-82. or. https://revistaeducacioninclusiva.es/index.php/REI/article/view/222

Mesias, O. (2010). La investigación cualitativa. Seminario de Tesis, Universidad Central de Venezuela. https://www.academia.edu/22351468/LA_INVESTIGACION_CUALITATIVA

Montes, R., Tapia, M. R., eta Yaber, L. (2011). Manual para docentes y estudiantes solidarios. http://www .clayss.org.ar/04_publicaciones/Natura2013.pdf

Puig, J. M., Batlle, R., Bosch, C., eta Palos, J. (2007). Aprendizaje servicio: Educar para la Ciudadanía. Octaedro.

Puig, J.M., Gijón, M., Martín, X., eta Rubio, L. (2011). Aprendizaje-Servicio y educación para la ciudadanía. Revista de educación, 45-67. or. http://www. revistaeducacion.educacion.es/re2011/re2011_03.pdf

Quecedo, R., eta Castaño, C. (2003). Introducción a la metodología de investigación cualitativa. Revista de Psicodidáctica, 14, 5-40. or. https://www.ehu.eus/ ojs/index.php/psicodidactica/article/view/142

Santa Maria Ikastetxea. (2020ko maiatzak 3). Nor gara? https://santamariaikastetxea.com/es/sobre-nosotros/quienes-somos.html.

Scott, K. E., eta Graham, J. A. (2015). Service-Learning: Implications for Empathy and Community Engagement in Elementary School Children. Journal of Experiential Education, 38(4), 354-372. or. http://dx.doi. org/10.1177/1053825915592889

Serrano, D. eta Ochoa A. (2019). El aprendizaje-servicio como potenciador de la educación inclusiva en la educación primaria. RIDAS, Revista Iberoamericana de Aprendizaje Servicio, 7, 37-54. or. https://revistes.ub.edu/index.php/RIDAS/article/view/28817

Tapia, M. N. (2000). La Solidaridad como Pedagogía. Ciudad Nueva.

Tapia, M. N. (2006). Aprendizaje y servicio solidario: algunos conceptos básicos. Programa Nacional Educación Solidaria.

Taylor, S. J., eta Bogdan, R. (1984). Introducción a los métodos cualitativos de investigación. Paidós.

Travers, R. (1971). Introducción a la investigación educacional. Paidós.

Yamauchi, L. A., Billig, S. H., Meyer, S., eta Hofschire, L. (2006). Student Outcomes Associated with Service-Learning in a Culturally Relevant High School Program. Journal of Prevention \& Intervention in the Community, 32(1-2), 149-164. or. https://doi.org/10.1300/J005v32n01_10'

Woods, P. (1989). La escuela por dentro. La etnografía en la investigación educativa. Paidós. 